\title{
Aerosol measurements with a shipborne Sun-sky-lunar photometer and collocated multiwavelength Raman polarization lidar over the Atlantic Ocean
}

\author{
Zhenping Yin ${ }^{1,2,3}$, Albert Ansmann ${ }^{1}$, Holger Baars ${ }^{1}$, Patric Seifert ${ }^{1}$, Ronny Engelmann ${ }^{1}$, Martin Radenz ${ }^{1}$, \\ Cristofer Jimenez ${ }^{1}$, Alina Herzog ${ }^{1}$, Kevin Ohneiser ${ }^{1}$, Karsten Hanbuch ${ }^{1}$, Luc Blarel ${ }^{4}$, Philippe Goloub ${ }^{4}$, \\ Gaël Dubois $^{4}$, Stephane Victori ${ }^{5}$, and Fabrice Maupin ${ }^{5}$ \\ ${ }^{1}$ Leibniz Institute for Tropospheric Research, Permoserstraße 15, Leipzig, Germany \\ ${ }^{2}$ School of Electronic Information, Wuhan University, Wuhan, China \\ ${ }^{3}$ Key Laboratory of Geospace Environment and Geodesy, Ministry of Education, Wuhan, China \\ ${ }^{4}$ Laboratoire d'Optique Amosphérique, Université des Sciences et Technologies de Lille, Villeneuve-d'Ascq, France \\ ${ }^{5}$ R\&D Department, Cimel Electronique, Paris, France
}

Correspondence: Zhenping Yin (zhenping@tropos.de)

Received: 1 April 2019 - Discussion started: 4 April 2019

Revised: 9 September 2019 - Accepted: 11 September 2019 - Published: 28 October 2019

\begin{abstract}
A shipborne Sun-sky-lunar photometer of type CE318-T was tested during two trans-Atlantic cruises aboard the German research vessel Polarstern from $54^{\circ} \mathrm{N}$ to $54^{\circ} \mathrm{S}$ in May/June and December 2018. The continuous observations of the motion-stabilized shipborne CE318-T enabled the first-time observation of a full diurnal cycle of aerosol optical depth (AOD) and column-mean Ångström coefficient of a mixed dust-smoke episode. The latitudinal distribution of the AOD from the shipborne CE318-T, Raman lidar and MICROTOPS II shows the same trend with highest values in the dust belt from 0 to $20^{\circ} \mathrm{N}$ and overall low values in the Southern Hemisphere. The linear-regression coefficients of determination between MICROTOPS II and the CE318-T were 0.988, 0.987, 0.994 and 0.994 for AODs at 380, 440, 500 and $870 \mathrm{~nm}$ and 0.896 for the Ångström exponent at $440-870 \mathrm{~nm}$. The root-mean-squared differences of AOD at 380, 440, 500 and $870 \mathrm{~nm}$ were $0.015,0.013,0.010$ and 0.009 , respectively.
\end{abstract}

\section{Introduction}

Aerosols influence the Earth's radiation budget, e.g., by absorption and scattering of solar radiation, and modulate cloud formation and cloud microphysical properties by serving as cloud condensation nuclei $(\mathrm{CCN})$ or ice-nucleating particles
(INPs). Although great progress has been made in aerosol observation technologies and climate modeling in recent years, the uncertainty of aerosol radiative forcing in global climate models is still very large due to our poor understanding of aerosol global distribution and aerosol-cloud interactions (Stocker, 2014).

Most of the current aerosol observations are land based. Spaceborne aerosol observations are available but most of them work in low Earth orbit, which cannot be used to resolve regional aerosol conditions as a function of time of day. However, the ocean, which covers more than $70 \%$ of the Earth's surface and represents one of the largest natural aerosol sources, can hardly be monitored by land-based instruments. In addition, marine aerosols, which are generated from the oceanic white cap and bubble bursting, impose significant contributions to the global direct radiative forcing (Satheesh and Moorthy, 2005). Long-range transport of aerosols from the continent plays an important role over the ocean as well, making the aerosol conditions even more complicated. The corresponding measurements of aerosol optical properties with passive remote sensing instruments can be performed on spaceborne, airborne or shipborne platforms. Spaceborne measurements can provide a global, long-term picture of the aerosol conditions. However, the data retrievals for spaceborne measurements require assumptions about the terrain (Hsu et al., 2013; Sayer et al., 2018), which go along 
with non-negligible errors. Airborne measurements have a large coverage (Karol et al., 2013), but the cost for each flight is high and the aircraft is sensitive to the weather conditions, which makes it less available for long-term observations. Although shipborne observations are challenging compared to land-based measurements due to the mobility of the platform and the potential for severe weather conditions, progress about Sun photometer technologies has been made over the last 20 years (Karol et al., 2013; Barreto et al., 2016; Livingston et al., 2003). While the first shipborne observations were performed during the NASA Sensor Intercomparison and Merger for Biological and Interdisciplinary Oceanic Studies (SIMBIOS) (Fargion et al., 1999), which was dedicated to intercalibration and validation for ocean color satellites, datasets meanwhile span over a long period of time (Smirnov et al., 2002; Knobelspiesse et al., 2004). The Maritime Aerosol Network (MAN, 2019), as a component of the AErosol RObotic NETwork (AERONET) (Holben et al., 2001), is the largest long-term aerosol observation network over the ocean (Smirnov et al., 2009). It has provided a unique dataset about aerosol optical depth (AOD) and precipitable water vapor (PWV) over the ocean even from Arctic to Antarctica. The data were largely used in the research about dust transport, satellite retrieval validation and atmospheric correction (Smirnov et al., 2011).

MICROTOPS II is the standard device of MAN. However, it is not dedicated to automatic maritime network observations. At least one operator is required to point the photometer to the Sun for a while to ensure stable measurements, which makes it less available for continuous, unattended measurements. Moreover, it cannot provide aerosol microphysical properties, including size distribution, scattering phase function and single scattering albedo because of missing sky radiance measurements (Smirnov et al., 2009). Therefore, a shipborne photometer based on the advanced Sun-sky-lunar photometry technology (CE318-T) was developed at Laboratoire d'Optique Atmosphérique (LOA), Lille, France, to cover this gap. This new device has all the capabilities of a land-based CE318-T (Barreto et al., 2016), including measurements of AOD from 340 to $1640 \mathrm{~nm}$, PWV, nighttime AOD and almucantar scans, which are required for the retrieval of aerosol microphysical properties. Therefore, it can be directly incorporated into AERONET. In addition, this instrument will be moved to the Arctic aboard RV Polarstern with joining the unprecedented Arctic research project MOSAiC (https://www.mosaic-expedition. org/, last access: 28 February 2019). The dataset regarding the Arctic seasonal aerosol conditions will definitely be helpful to quantify human effects on global climate change. But before that, we need to address how the shipborne CE318$\mathrm{T}$ setup behaves, how much influence of the sea spray could bring and the uncertainty of the AOD measurements under oceanic conditions.

In order to answer these questions, this instrument was tested in the framework of the OCEANET project (Macke

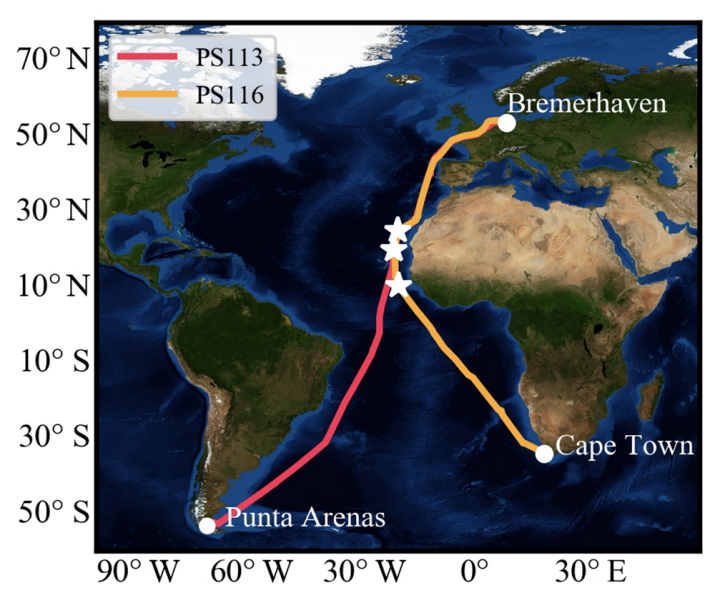

Figure 1. Ship tracks for RV Polarstern cruises PS113 and PS116. PS113 started from Punta Arenas, Chile, on 7 May 2018 and arrived at Bremerhaven, Germany, on 11 June 2018. PS116 started from Bremerhaven, Germany, on 11 December 2018 and arrived at Cape Town, South Africa, on 11 December 2018. White stars mark the location of the case studies presented in Sect. 3.

et al., 2010) during the past two RV Polarstern cruises, PS113 and PS116. PS113 started at Punta Arenas, Chile, on 7 May 2018 and ended at Bremerhaven, Germany, on 11 June 2018. In the case of PS116, RV Polarstern departed from Bremerhaven on 11 November 2018 and arrived at Cape Town, South Africa, on 11 December 2018 (see Fig. 1 for the ship tracks). Equipped with sophisticated groundbased instruments, including a portable and automated Raman and polarization lidar system Polly ${ }^{\mathrm{XT}}$ (Engelmann et al., 2016; Althausen et al., 2009), microwave radiometer, meteorological station, shadowband radiometer, full-sky imager and MICROTOPS II, it provided a unique opportunity to evaluate the capabilities of the photometer prototype and collect useful feedback for its future developments.

This paper is organized as follows. In Sect. 2, we give a description of the shipborne CE318-T and other applied instruments and data in this paper. Then, in Sect. 3.1, we evaluate the daytime results from the shipborne CE318-T through comparisons with MICROTOPS II and we present the diurnal measurements of the shipborne CE318-T to validate the nighttime AOD with collocated Raman lidar measurements. In Sect. 3.2, we present two detailed case studies to evaluate the performance of the shipborne CE318-T under pure marine conditions and during the presence of lofted Saharan dust layers. Furthermore, we will demonstrate the potential of the combination of the shipborne CE318-T measurements and the lidar observations for a detailed characterization of a dust case. Finally, in Sect. 4, summarizing and concluding remarks are given. 


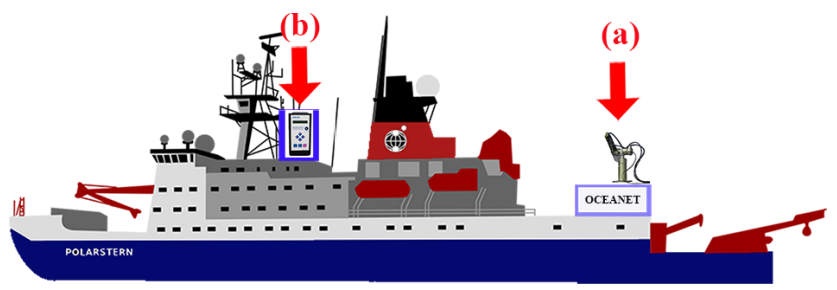

Figure 2. Photometer and lidar observations aboard RV Polarstern. MICROTOPS II observations were performed at site (b). Lidar and shipborne CE318-T observations were conducted at site (a).

\section{Instrumentation}

The instruments of the OCEANET project are dedicated to the investigation of aerosol, cloud and radiation interactions over the remote Atlantic Ocean and the characterization of contrasts between northern- and southern-hemispheric aerosol and cloud conditions. The OCEANET project started in fall of 2009 (Kanitz, 2012). Nearly all the instruments were mounted on the roof of the OCEANET container except the indoor Polly ${ }^{\mathrm{XT}}$ lidar. The container was located on the helicopter deck, which is behind the bridge, for these two cruises (see Fig. 2). The MICROTOPS II measurements were conducted on the bridge (see Fig. 2). It should be noted that the "anthropogenic" smoke from the funnel of the ship could contaminate the shipborne CE318-T measurements. However, this was a compromise between avoiding strong head winds, sea spray and smoke. Nevertheless, we only found an AOD shift of 0.002 at $500 \mathrm{~nm}$ between shipborne CE318-T and MICROTOPS II and this was well within the calibration uncertainty of these instruments. Therefore, the influence of the smoke was negligible for our comparisons.

\subsection{Shipborne CE318-T}

The shipborne CE318-T in Fig. 3 was developed to enable AOD measurements on mobile platforms and to expand the AERONET coverage to the vast ocean area (Goloub et al., 2017). In principle, the instrument is similar to the traditional CE318-T (Barreto et al., 2016) and has nearly the same steps for installation. The apparatus consists of the optical head, rotational base, control unit, air-pumping component, weather stop component, compass and GPS modules (see Fig. 3C). The optical head was the same like the other land-based CE318-T. The GPS receiver and compass module (SIMRAD HS60) were fixed on the platform together with the photometer robot to assure the same motions. In order to track the Sun continuously over the ship, the photometer will firstly go to the Sun with the last information (date, time, geolocation, heading, pitch and roll) from the GPS receiver and compass module. This can help the photometer point to the Sun if the ship does not turn quickly. If the photometer does not see the Sun, which can be determined through the digital number from direct Sun measurements, the head will be con-

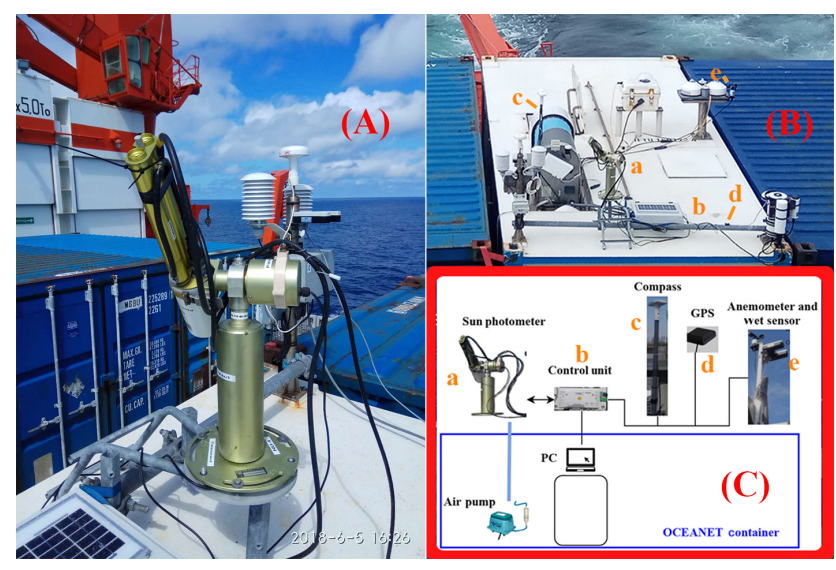

Figure 3. Shipborne Sun photometer CE318-T taking measurements on the RV Polarstern (A), top view of the Sun photometer on the top of the container $(\mathbf{B})$ and the sketch of the Sun photometer setup (C). Lowercase letters (a-e) are used to relate the technical scheme (C) to the actual setup shown in panel (B).

trolled to search the sky at $45^{\circ}$ in the left and right horizontal panels. When it detects the Sun, the new position will be used to calculate the turning angle of the ship and then to correct the azimuth position for next measurements. When the Sun is in the tracking field of view $\left(\sim 10^{\circ}\right)$, the photometer will switch into tracking mode like a regular photometer. However, unlike a conventional CE318-T, the tracking mode by using the four-quadrant detector will keep working to compensate the motions of the ship during all the SUN triplet measurements. It is the same procedure for the MOON triplet as well. The air-pumping module generates compressed drycleaned air to the collimator to prohibit the contamination of the optical window by ambient sea spray. Meanwhile, we changed the wet sensor (a resistor) to an optical rain sensor to prevent the influence of the strong corrosion from the sea spray. Furthermore, we added an anemometer to help stop the system, because the robot itself will vibrate when wind speed increases to values above $45 \mathrm{~km} \mathrm{~h}^{-1}$. During the two measurement cruises, however, we chose a limit of $40 \mathrm{~km} \mathrm{~h}^{-1}$ to ensure measurements that are unaffected by wind-driven vibrations.

The photometer arrangement is very robust and robotic to conduct 24/7 measurement without special care. The new rain sensor and anemometer worked well even under stormy and rainy weather conditions during the two Polarstern cruises. The collected data were finally transferred to the LOA server for further analysis.

The prototype of the shipborne CE318-T, which was deployed for our study, has 10 channels with nominal wavelengths of 340, 380, 440, 500, 532, 670, 870, 937, 1020 and $1064 \mathrm{~nm}$. It can provide AOD values at nine wavelengths and PWV during both daytime and nighttime. It also has the potential of performing almucantar scanning. Further efforts and investigations, such as complex compass data analysis, 
will be made to utilize these data for the retrievals of aerosol microphysical properties. The data processing, which we applied, followed the same procedure described in Barreto et al. (2016). In addition, it is required to save the geolocation data along with the AOD, since the platform keeps moving all the time.

\subsection{MICROTOPS II}

AOD and PWV measurements were also performed with a handheld MICROTOPS II (Ichoku et al., 2002; Smirnov et al., 2002) within the framework of MAN, which was proceeded by SIMBIOS. It was calibrated before and after the cruise by NASA Goddard Space Flight Center. This type of MICROTOPS II has five channels at 380, 440, 675, 870 and $936 \mathrm{~nm}$.

There are three data quality levels for the AOD both from shipborne CE318-T and from MICROTOPS II: level 1.0 with no cloud screening, level 1.5 with cloud screening and level 2.0 (Level 1.6 for shipborne CE318-T) for cloud screening and quality assurance (Smirnov et al., 2011). We used level 2.0 (level 1.6 for shipborne CE318-T) AOD at 380, 440, 500 and $870 \mathrm{~nm}$ for our analysis. However, we need to point out that $500 \mathrm{~nm}$ AOD from the MICROTOPS II database was interpolated with using the Ångström exponent between 440 and $870 \mathrm{~nm}$ wavelengths.

\subsection{Polly $\mathrm{XT}$}

The Raman polarization lidar (Polly ${ }^{\mathrm{XT}}$ ) was continuously operated during the entire cruise. Polly ${ }^{\mathrm{XT}}$ has two telescopes with diameters of 50 and $300 \mathrm{~mm}$, respectively. There are 12 detection channels connected with these two telescopes to cover the detection range from near the surface $(\sim 120 \mathrm{~m})$ up to $4 \mathrm{~km}$ (near range) and from $800 \mathrm{~m}$ to more than $10 \mathrm{~km}$ (far range), respectively. It has eight far-range channels for wavelengths of $355 \mathrm{~nm}$ (total: elastic signal and cross polarized: filtered by a polarizer), 387, 407, 532 (total and cross polarized), 607 and $1064 \mathrm{~nm}$, four near-range channels for wavelengths of 355, 387, 532 and $607 \mathrm{~nm}$ (Engelmann et al., 2016). The signal can be used to retrieve the vertical profiles of volume depolarization ratio at 355 and $532 \mathrm{~nm}$, extinction coefficient at 355 and $532 \mathrm{~nm}$, and backscatter coefficient at 355,532 and $1064 \mathrm{~nm}$, which are related to aerosol bulk properties. Hence, particle depolarization ratios at 355 and $532 \mathrm{~nm}$ and lidar ratios at 355 and $532 \mathrm{~nm}$ can be retrieved, which are sensitive to particle size, shape and chemistry properties (Freudenthaler et al., 2009; Baars et al., 2016). The backscatter coefficient $\beta$ and extinction coefficient $\alpha$ are good indicators for particle concentration (Ansmann and Müller, 2005). The lidar ratio $S$, which is the ratio of extinction to backscatter coefficient, describes the particle absorption ability (Müller et al., 2007; Groß et al., 2011a). Absorbing particles like soot and black-carbon-containing particles have a higher lidar ratio than, e.g., non-absorbing sulfate aerosol particles. Ångström exponent ̊ (Ångström, 1964) which describes the relationship between optical properties (backscatter, extinction) at two wavelengths can be used as an indicator for particle size (Baars et al., 2016; Ansmann et al., 2002). Normally, large particles like dust particles have a small $\AA(<0.5)$. On the contrary, small particles like biomass combustion aerosols and most continental aerosols, have a larger $\AA$ (> 1.0) (Müller et al., 2007; Baars et al., 2016; Eck et al., 1999). Therefore, aerosol layers with different physical and chemical properties, like marine aerosol, dust and smoke, can be characterized based on these retrieving results.

The near-range telescope can suppress the range of incomplete overlap between the laser pulse and the telescope fieldof-view to $120 \mathrm{~m}$, which enabled us to capture the aerosol distribution and evolution inside the marine boundary layer (MBL) (Kanitz et al., 2013; Engelmann et al., 2016). In order to avoid any damage of the photon-counting detectors from strong solar radiation, the lidar system was turned off when the solar elevation angle exceeded $70^{\circ}$ and the $407 \mathrm{~nm}$ channel was turned off routinely at daytime.

In order to calculate the AOD from the lidar observations, the Raman method (Ansmann et al., 1992) and the KlettFernald method (Fernald et al., 1972) were utilized for nighttime and daytime measurements, respectively. The Fernald method needs the assumption of a lidar ratio, which is dependent on aerosol types. In our analysis, lidar ratios of $20 \mathrm{sr}$ (20 and $20 \mathrm{sr}$ ), $50 \mathrm{sr}$ (50 and $50 \mathrm{sr}$ ) were used for marine aerosols and dust at $355 \mathrm{~nm}(532$ and $1064 \mathrm{~nm})$ (Groß et al., 2011a). The assumption about lidar ratio would lead to a maximum relative error of $20 \%$ for $\mathrm{AOD}$, which is dependent on the deviations of lidar ratio for the aerosol layers (Kafle and Coulter, 2013; Hughes et al., 1985). The Raman method can achieve better accuracy, because it does not need the critical assumption of lidar ratio (Ansmann et al., 1992). However, it can lead to relatively large statistical errors, due to the very weak Raman signal. Therefore, in order to reduce the statistical error to less than $15 \%$, we accumulated the signal over $1 \mathrm{~h}$ and used a vertical smoothing window to increase the signal-to-noise ratio (Mattis et al., 2004; Groß et al., 2011b).

\subsection{Supplementary instruments and data sources}

Temperature, pressure and relative humidity $(\mathrm{RH})$ profiles were obtained from radiosonde ascents. The radiosondes were launched aboard the RV Polarstern at 11:00 UTC on each day. For times deviating more than $3 \mathrm{~h}$ from the radiosonde launch, Global Data Assimilation System $1^{\circ}$ resolution (GDAS1) meteorology data (Kanamitsu, 1989) was used in the lidar data analysis. These data are processed every $3 \mathrm{~h}$ per day with a spatial resolution of $1^{\circ}$ (latitude, longitude) by an atmospheric model provided by National Centers for Environmental Prediction (NCEP). In addition, the Hybrid Single-Particle Lagrangian Integrated Trajectory (HYS- 

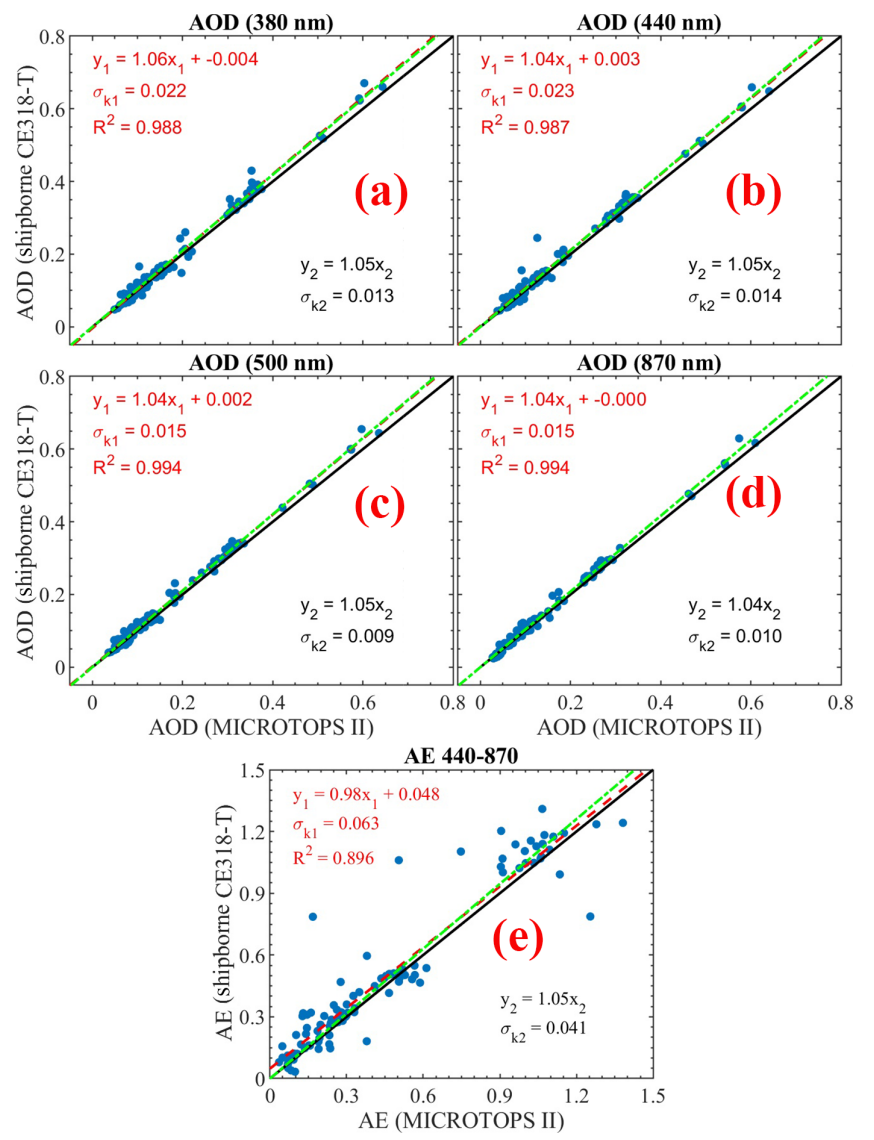

Figure 4. Linear regression of AOD (a, b, c, d) and Ångström exponent (e) from the shipborne CE318-T and MICROTOPS II observations. The data points are mean values within a sliding window of $20 \mathrm{~min}$. Overall, 115 data pairs are used in this regression. The dashed red line is the regression result with free intercept relationship and the dot-dashed green line represents the regression relationship with forced intercept through 0 .

PLIT) model (Draxler, 2011) was used for backward trajectory analysis.

\section{Results}

\subsection{Validation of shipborne CE318-T}

\subsubsection{Daytime validation with MICROTOPS II}

The AOD measurements were conducted with MICROTOPS II, Polly ${ }^{\mathrm{XT}}$ and shipborne CE318-T simultaneously during the daytime and with Polly XT and shipborne CE318-T at nighttime. In order to evaluate the reliability and data quality of the shipborne CE318-T, we showed linear regressions between MICROTOPS II AOD and shipborne CE318$\mathrm{T}$ AOD in Fig. 4. A good linear relationship was found between the shipborne CE318-T and MICROTOPS II with $R^{2}$ (coefficient of determination) of $0.988,0.987,0.994$ and
0.994 for AODs at $380,440,500$ and $870 \mathrm{~nm}$, respectively, and of 0.896 for the Ångström exponent. The Angström exponent is sensitive to the measurement error at clean conditions with AOD less than 0.05. Therefore, the scatter in the respective correlation in Fig. 4e is acceptable.

In order to study how the AOD from MICROTOPS II and CE318-T agreed with each other, we used the BlandAltman plots (Willmott, 1982; Knobelspiesse et al., 2019; Bland and Altman, 1986) to visualize AOD difference $\left(\triangle \mathrm{AOD}=\mathrm{AOD}_{\mathrm{CE} 318-\mathrm{T}}-\mathrm{AOD}_{\text {MICROTOPS }}\right)$ against the AOD mean $\left(\overline{\mathrm{AOD}}=\left(\mathrm{AO} D_{\mathrm{CE} 318-\mathrm{T}}+\mathrm{AOD}_{\text {MICROTOPS }}\right) / 2\right.$, which can clearly display the bias and systematic effects. For this analysis, we only took the data pairs with the $500 \mathrm{~nm}$ AOD between 0.04 and 0.2 , according to the WMO criteria for traceability (WMO, 2005). We used the metric, which is the percentage of $\overline{\mathrm{AOD}}$ that falls out of the boundary of the mean difference $\pm 1.96 \times$ the root-mean-squared AOD difference, to quantify the agreement of two measurements. According to the statistical analysis in Knobelspiesse et al. (2019) and Giavarina (2015), the criteria of $5 \%$ for the metric of dropout rate normally can be used to determine the agreement is good or not, if the AODs from two instruments were independent and the AOD difference followed normal distribution. In order to test whether we can take the same criteria, we use the Anderson-Darling test to evaluate the normality and Chi2 test to evaluate independence. The results showed the AOD measurements between CE318-T and MICROTOPS II were independent but the AOD difference did not follow a normal distribution, which could state potential systematic errors either from MICROTOPS II or from the CE318-T. In this case, the criteria of $5 \%$ on the dropout rate can only serve as an indicator for agreement.

From Fig. 5, we found small positive biases of 0.0019, $0.0050,0.0052$ and 0.0027 for AODs at 380, 440, 500 and $870 \mathrm{~nm}$, respectively, for the CE318-T compared with MICROTOPS II and the root-mean-squared AOD differences are 0.0149, 0.0128, 0.0099 and 0.0090, respectively. Based on studies of Morys et al. (2001) and Ichoku et al. (2002), the estimated uncertainties of AOD from MICROTOPS II decrease from about 0.02 at $340 \mathrm{~nm}$ to about 0.01 at $870 \mathrm{~nm}$, as was derived from comparisons with AERONET master field instruments. This means we can only validate other instruments to this level of accuracy by taking the MICROTOPS II as the reference. The dropout rates of the AOD difference were $3.80 \%, 3.80 \%, 7.59 \%$ and $2.53 \%$ at 380,440 , 500 and $870 \mathrm{~nm}$, respectively. These results show that the AODs at 380,440 and $870 \mathrm{~nm}$ from the shipborne CE318$\mathrm{T}$ were in good agreement with MICROTOPS II. AOD at $500 \mathrm{~nm}$ was a little bit worse, as the dropout rate exceeded $5 \%$. But, as we mentioned in Sect. 2.2, the $500 \mathrm{~nm} \mathrm{AOD}$ from the MICROTOPS II was interpolated from other wavelengths, which might go along with additional uncertainties from assuming a certain Ångström exponent. Overall, we can conclude the daytime capabilities for the shipborne CE318- 

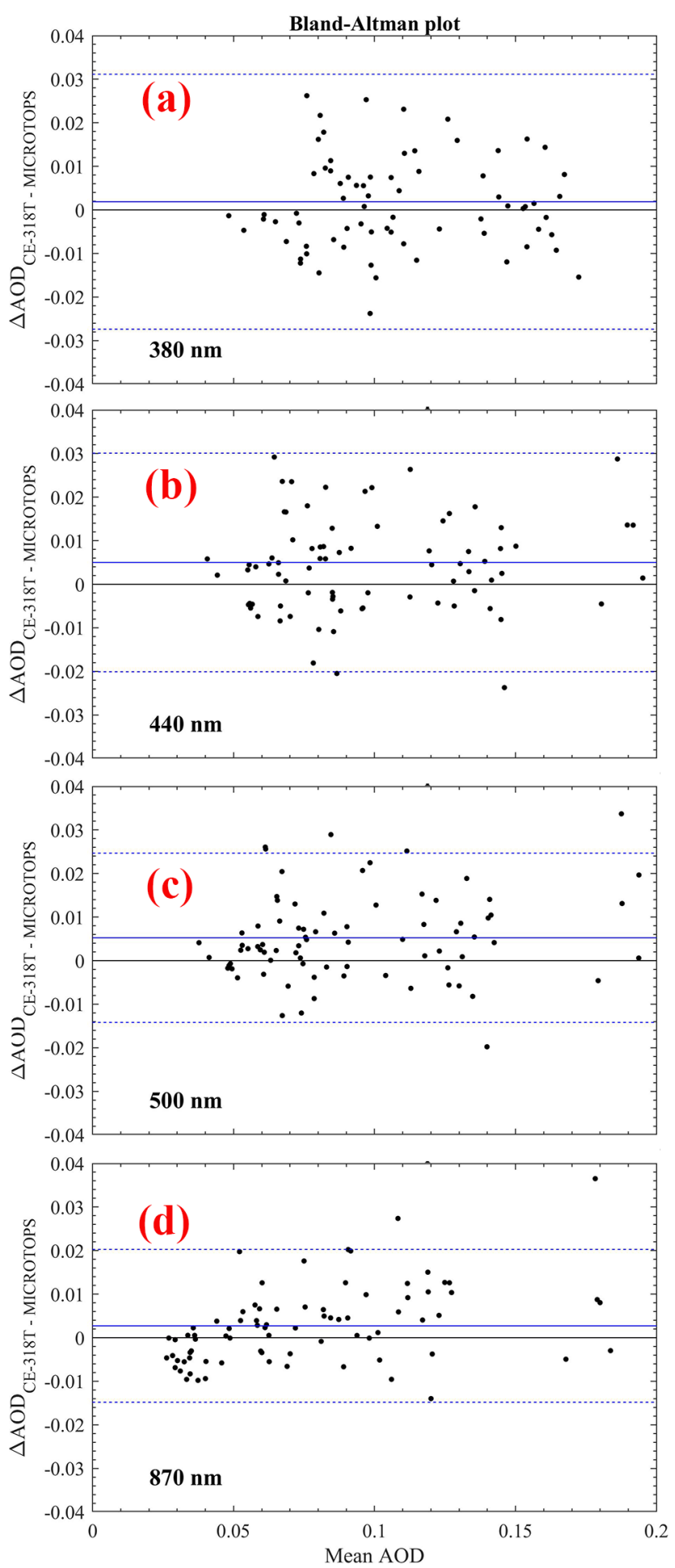

Figure 5. Bland-Altman plots for AOD differences with mean AOD $\left(\left(\mathrm{AOD}_{\mathrm{CE}-318 \mathrm{~T}}+\mathrm{AOD}_{\mathrm{MICROTOPS}}\right) / 2\right)$ at 380 (a), 440 (b), 500 (c) and $870 \mathrm{~nm}$ (d). The solid black-colored and blue-colored lines represent the zero line and the mean AOD differences, respectively. Dotted blue-colored lines represent the mean AOD plus/minus the root-mean-squared AOD differences.
$\mathrm{T}$ under the real marine conditions are as good as those of MICROTOPS II.

\subsubsection{Nighttime comparisons with Polly $\mathrm{XT}$}

The shipborne CE318-T has the capability to conduct nighttime measurements. This feature can help us to investigate the diurnal evolution of marine aerosols and dust layers over the ocean. However, this function is more challenging than the daytime measurement as moon tracking is much more sensitive to errors in the leveling adjustment and coordination and orientation data from the compass. Therefore, we need to analyze the accuracy of the nighttime measurements. In Fig. 6, we present the full diurnal measurements from the shipborne CE318-T, Polly ${ }^{X T}$ and MICROTOPS II on 26 November 2018. On this day, RV Polarstern had just passed Cabo Verde and was heading towards Cape Town. A layer of mixed dust and pollution aerosol was observed throughout the whole day. This finding is corroborated by the measurements of the $532 \mathrm{~nm}$ volume linear depolarization ratio (Fig. 6c) and a backward trajectory analysis, which is shown in Fig. 7. The backward trajectories show that the air mass that was observed between 1 and $3 \mathrm{~km}$ height (see Fig. 8a) on 26 November 2018 originated from the Saharan desert and spent $6 \mathrm{~d}$ over Chad and Niger before crossing RV Polarstern. All the backward trajectories including the ones for 500 and $1000 \mathrm{~m}$ arrival height crossed the active biomass-burning regions $2 \mathrm{~d}$ before arriving RV Polarstern. Therefore, the advected dust layer probably took up a large amount of biomass-burning aerosols over central Africa, as all the aerosol parameters in Fig. 8c-e also indicate. In order to evaluate the shipborne CE318-T AOD measurements at nighttime, AOD from Polly ${ }^{\mathrm{XT}}$ was calculated based on the extinction coefficient retrieved with the Raman method (Ansmann et al., 1992). Above 1.5 to $6 \mathrm{~km}$, the extinction coefficient was taken from the far-range channels, and between 0.3 and $1.5 \mathrm{~km}$ data from the near-range channels were used. Below $0.3 \mathrm{~km}$, the extinction coefficient was considered to be constant with height, as displayed in Fig. 8b. Furthermore, we have checked the signal above $6 \mathrm{~km}$ height and found no additional aerosol layers. The overall relative error of AOD with using this approach was $11 \%-15 \%$, according to the error analysis (Ansmann et al., 1992; Mattis et al., 2004; Groß et al., 2011b). The time series of AOD can be found in Fig. 6a. The deviation between nighttime shipborne CE318-T and lidar observations of $532 \mathrm{~nm}$ AOD was less than 0.03. Daytime measurements from the shipborne CE318-T are also in good agreement with MICROTOPS II at 11:00 UTC, with deviations of 0.01 and 0.01 for the $500 \mathrm{~nm}$ AOD and the Ångström exponent, respectively.

\subsection{Case studies}

In Fig. 9, the latitudinal distributions of AOD at $500 \mathrm{~nm}$ $(532 \mathrm{~nm})$ from the three instruments are displayed for the 


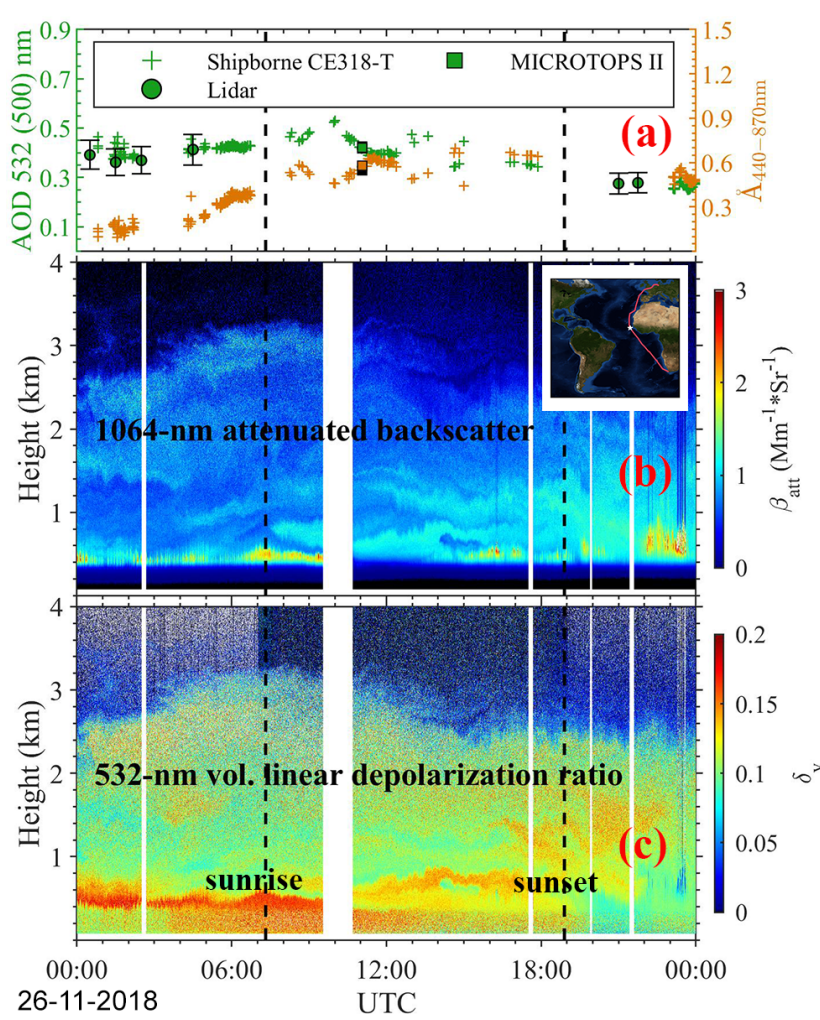

Figure 6. Shipborne aerosol observation with CE318-T, MICROTOPS II and Polly ${ }^{X T}$ lidar at conditions with a mixture of dust and smoke on 26 November 2018. (a) Comparison of $532 \mathrm{~nm}$ AOD from shipborne CE318-T and Polly XT lidar observations and $500 \mathrm{~nm}$ AOD from MICROTOPS II measurements and Ångström exponent at $440-870 \mathrm{~nm}$ obtained from shipborne CE318-T and MICROTOPS II data, (b) mixed layer extended to about $3.5 \mathrm{~km}$ height as observed with lidar in terms of $1064 \mathrm{~nm}$ attenuated backscatter and (c) volume depolarization ratio indicating a dust-contaminated MBL. The narrow vertical white stripes are the lidar depolarization calibration periods and the thick white vertical stripe at 10:00 UTC is the routine turn-off time to avoid solar damage at noon.

data collected during the two RV Polarstern cruises (PS113 and PS116). In both Fig. 9a and b, all measurements show the same trend with peak values between 0 and $20^{\circ} \mathrm{N}$ (Kanitz et al., 2013), which is a major outflow region of Saharan dust and biomass-burning aerosols. For PS113, this belt was mainly filled with dust particles, because the Ångström exponent at $440-870 \mathrm{~nm}$ was less than 0.4 and AOD at $500 \mathrm{~nm}$ exceeded 0.5, which are typical values for Saharan dust (Toledano et al., 2007; Rittmeister et al., 2017). However, for PS116, the air mass in this belt showed a mixture of dust and smoke because the Ångström exponent at $440-870 \mathrm{~nm}$ was larger than 1 (Baars et al., 2012). This finding is corroborated by the lidar measurements and backward trajectories as well. On the contrary, the Southern Hemisphere contains less anthropogenic aerosols and dust. In most cases, marine aerosol dominated our observations. Nevertheless, lofted biomassburning aerosol from Brazil was observed at $25^{\circ} \mathrm{S}$ during
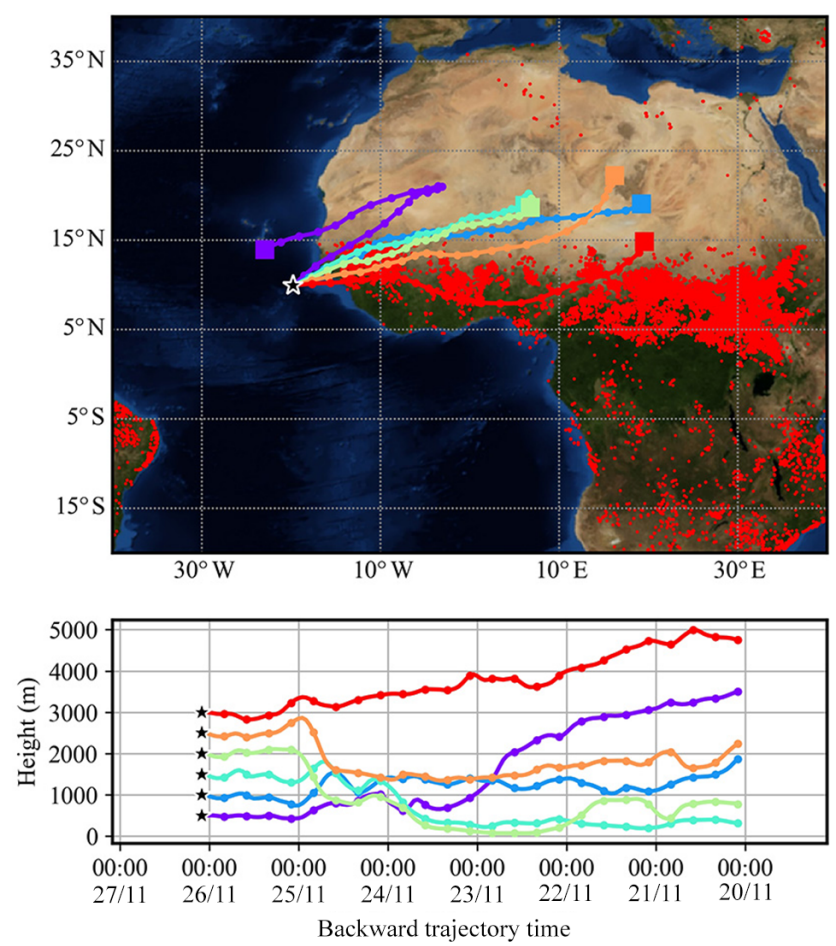

Figure 7. NOAA HYSPLIT backward trajectories arriving at RV Polarstern (black star with white border, $10.04^{\circ} \mathrm{N}, 19.82^{\circ} \mathrm{W}$ ) on 26 November 2018 at 02:00 UTC. Red dots are the fire spots detected by MODIS aboard the Terra and Aqua satellites over the period from 20 to 26 November 2018.

PS113. This event was also captured by Polly ${ }^{\mathrm{XT}}$, which revealed a layer top height of $2 \mathrm{~km}$, which is not shown here.

In order to illustrate the aerosol vertical distribution over the Atlantic Ocean and to investigate the behavior of the shipborne CE318-T under different aerosol conditions, we present in the following two subsections the results from shipborne CE318-T, Polly XT and MICROTOPS II observations for pure marine conditions and for cases with Saharan dust outbreaks. Detailed analyses were applied based on the diurnal measurements from the shipborne CE318-T and Polly ${ }^{\mathrm{XT}}$ lidar and daytime measurements from MICROTOPS II.

\subsubsection{Marine aerosol conditions}

On 23 November 2018, RV Polarstern was west of Western Sahara and approaching Cabo Verde. A northwesterly airflow and clean marine conditions prevailed. The measurements from shipborne CE318-T and Polly ${ }^{\mathrm{XT}}$ are shown in Fig. 10. According to the $532 \mathrm{~nm}$ attenuated backscatter, typical marine aerosol conditions were observed. The $532 \mathrm{~nm}$ volume depolarization ratio was less than 0.05 at heights below $1.8 \mathrm{~km}$, which means that the marine boundary layer was dominated by spherical sea salt particles. The backward trajectories shown in Fig. 11 demonstrate that the air mass was 




Figure 8. Raman lidar observation on 26 November 2018 at 02:00-03:00 UTC. (a) Particle backscatter coefficients, (b) particle extinction coefficients (Raman lidar method), (c) lidar ratio, (d) Ångström exponents computed from different wavelength pairs in panels (a) and (b), (e) volume $\left(\delta_{\mathrm{vol}}\right)$ and particle $\left(\delta_{\mathrm{par}}\right)$ depolarization ratios and (f) relative humidity (blue) and temperature (red) from radiosonde observations and GDAS1 data.

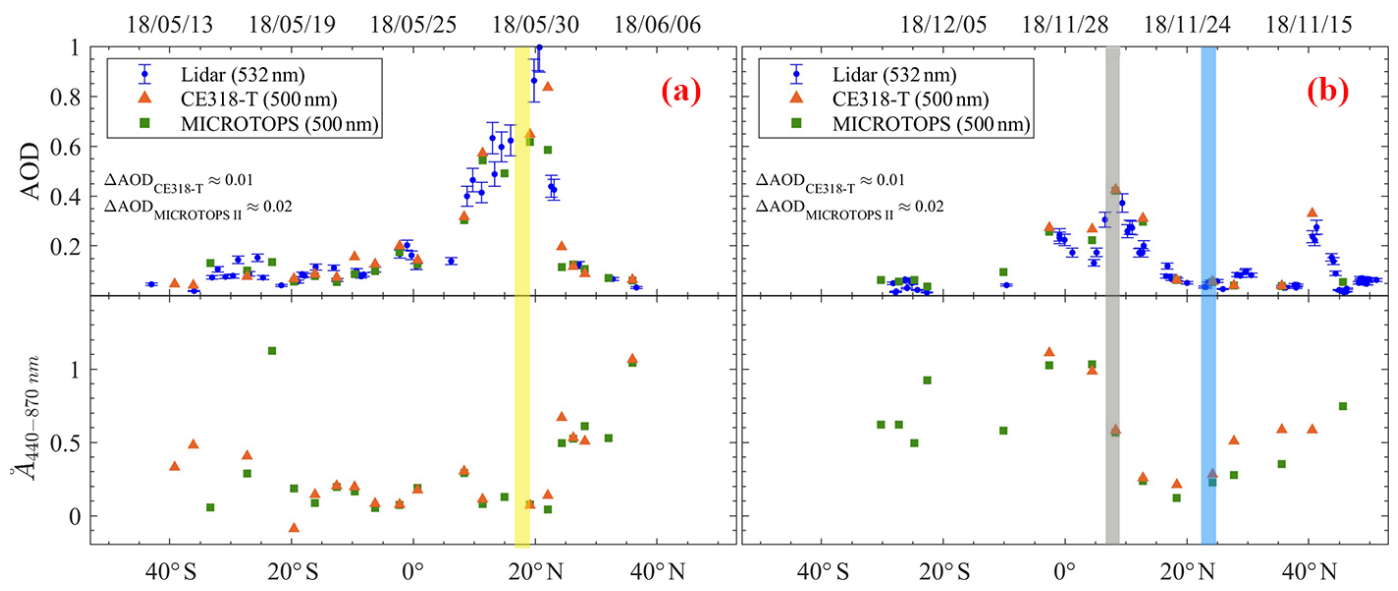

Figure 9. (a) Latitudinal distribution of daily mean AOD measured with Polly ${ }^{X T}$ lidar, MICROTOPS II and shipborne CE318-T. Panels (a) and (b) show the results from PS113 and PS116, respectively. The three vertical colored stripes indicate the cases discussed in Sect. 3.1 .2 and 3.2 (yellow: Saharan dust in Fig. 13; grey: diurnal measurements in Fig. 6; blue: pure marine conditions in Fig. 10). Uncertainty in shipborne CE318-T and MICROTOPS II observations was derived according to Smirnov et al. (2009, 2011).

mainly carried over the ocean during the past $4 \mathrm{~d}$. Furthermore, no additional aerosol layers were observed above $2 \mathrm{~km}$ height. The mean AOD at $532 \mathrm{~nm}$ from 08:30 to 11:00 UTC based on shipborne CE318-T measurements was $0.06 \pm 0.01$ and mean Ångström exponent at $440-870 \mathrm{~nm}$ was $0.26 \pm$ 0.03 , These are typical values for marine aerosols, which are dominated by coarse-mode sea salt particles (Smirnov et al, 2006). The mean AOD at $532 \mathrm{~nm}$ and mean Ångström exponent at $440-870 \mathrm{~nm}$ from MICROTOPS II were $0.05 \pm 0.01$ and $0.20 \pm 0.03$, which are in good agreement with the shipborne CE318-T.

Detailed height-resolved aerosol information is displayed in Fig. 12. According to the RH profile (Fig. 12d), the marine layer reached up to about $2 \mathrm{~km}$ height. The mean extinction coefficient was $38.5,27.4$ and $19.2 \mathrm{Mm}^{-1}$ at 355,532 and $1064 \mathrm{~nm}$, respectively, as derived from the Fernald method (Fernald et al., 1972) and assuming a fixed lidar ratio of $20 \mathrm{sr}$ (Groß et al., 2011a). The particle depolarization ratios below $1.6 \mathrm{~km}$ height were less than 0.02 at 355 and $532 \mathrm{~nm}$. 


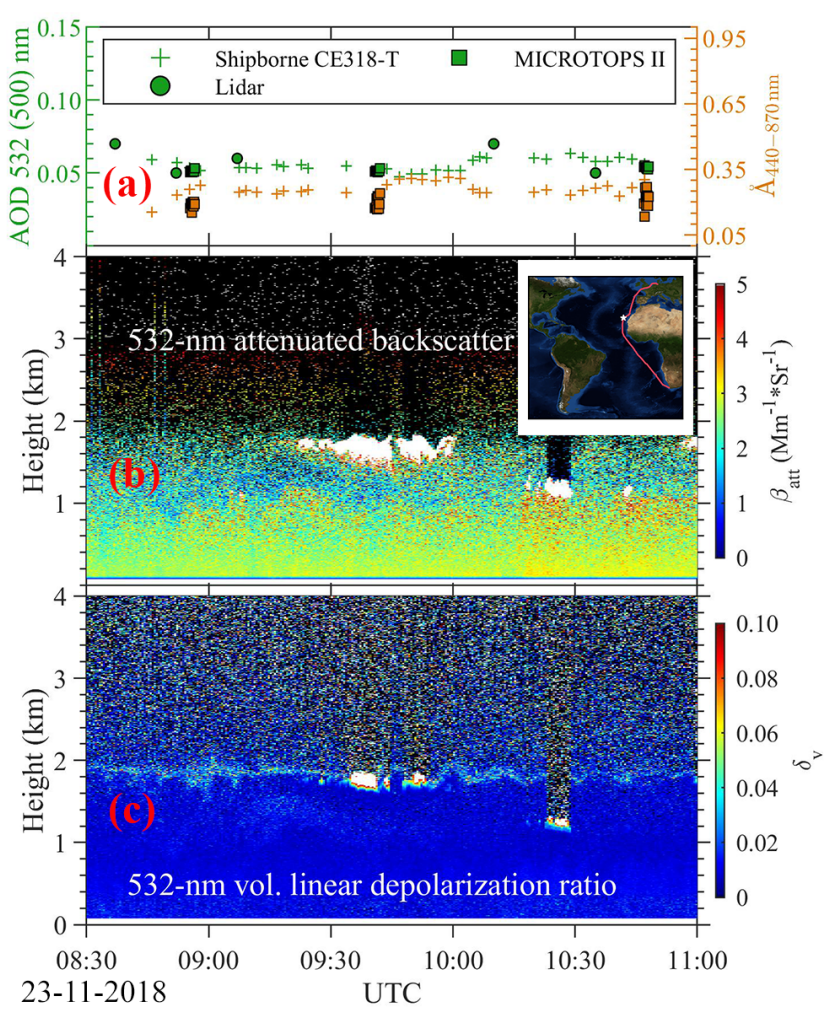

Figure 10. Shipborne aerosol observation with the shipborne CE318-T, MICROTOPS II and Polly XT lidar at pure marine conditions on 23 November 2018. (a) Comparison of $532 \mathrm{~nm}$ AOD measured with shipborne CE318-T and Polly XT lidar and $500 \mathrm{~nm}$ AOD from MICROTOPS II and Ångström exponent at 440-870 nm from shipborne CE318-T and MICROTOPS II, (b) marine aerosol layer reaching to about $2 \mathrm{~km}$ height, partly topped with cumulus clouds (white area), observed with lidar in terms of $532 \mathrm{~nm}$ attenuated backscatter, and (c) volume depolarization ratio, indicating pure marine conditions (very low depolarization ratio caused by the spherical droplets as sea salt particle was deliquescent at $\mathrm{RH}>70 \%$ ) with dried cubic-like sea salt particles at the top (slightly enhanced depolarization ratio) at $\mathrm{RH}<45 \%$.

From 1.7 to $2.0 \mathrm{~km}$ height, the particle depolarization ratio increased to peak values of $0.09(0.08)$ at $355 \mathrm{~nm}(532 \mathrm{~nm})$ and RH decreased to $10 \%$ according to the GDAS1 data. These are good indicators for the presence of dried sea salt particles (Haarig et al., 2017; Bohlmann et al., 2018). When RH drops to below $45 \%$, the spherical marine aerosol particles start to crystallize and become cubic-like in shape. These cubic dry sea salt particles will introduce a relatively strong depolarized signal and lead to the increase of particle depolarization ratio (Haarig et al., 2017).

\subsubsection{Saharan dust}

When RV Polarstern approached Cabo Verde islands, a dust outbreak was observed from 27 to 31 May 2018. The event started with a mixture of dust and smoke above the MBL.

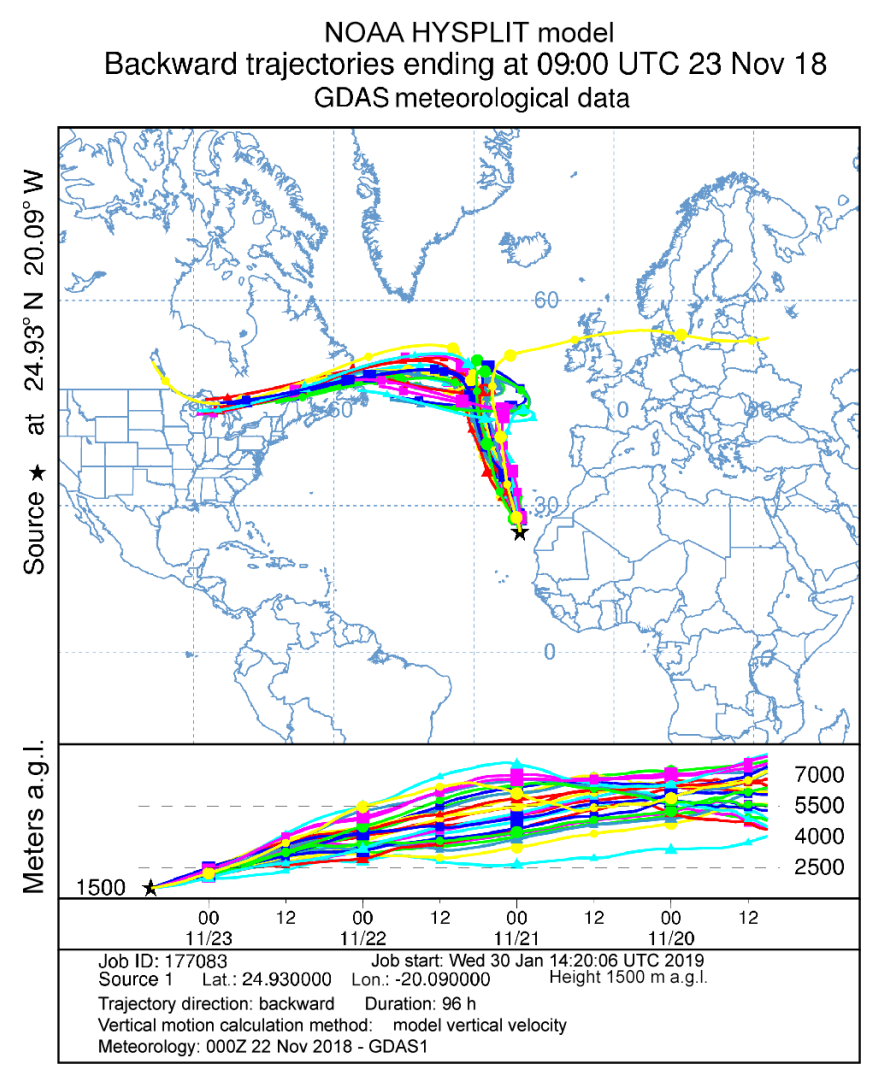

Figure 11. The $4 \mathrm{~d}$ HYSPLIT backward trajectory ensemble arriving at $1500 \mathrm{~m}$ height above RV Polarstern (black star, $18.41^{\circ} \mathrm{S}$, $32.93^{\circ} \mathrm{W}$ ) on 23 November 2018 at 22:00 UTC.

Starting on 30 May 2018, the layer ascended to above $1.5 \mathrm{~km}$ height and was dominated by pure Saharan dust particles.

The MICROTOPS II, shipborne CE318-T and lidar measurements from 16:00 to 17:00 UTC on 30 May 2018 are displayed in Fig. 13. According to Fig. 13a, the results from the shipborne CE318-T and MICROTOPS II agree well with mean $500 \mathrm{~nm}$ AOD of $0.66 \pm 0.03$ and $0.62 \pm 0.02$ and a mean Ångström exponent at $440-870 \mathrm{~nm}$ of $0.08 \pm 0.02$ and $0.07 \pm 0.01$, respectively. Both results indicate the presence of a large amount of large dust particles. In Fig. 13c, we can see a layer between 0.6 and $1 \mathrm{~km}$ height causing slightly enhanced volume depolarization ratio and a dust layer located between 1.5 and $5 \mathrm{~km}$ height with large volume depolarization ratio. Inside the MBL, the volume depolarization ratio was quite low, which indicates that the contamination caused by dust sedimentation was small.

In Fig. 14, we present the averaged vertical profiles from the lidar Polly $\mathrm{XT}$. The extinction coefficient was retrieved with the Fernald method, assuming lidar ratios of $60 \mathrm{sr}$ $(355 \mathrm{~nm}), 45 \mathrm{sr}(532 \mathrm{~nm})$ and $54 \mathrm{sr}(1064 \mathrm{~nm})$ for the dust layer and of $25 \mathrm{sr}(355,532$ and $1064 \mathrm{~nm})$ for the MBL. The lidar ratios at 355 and $532 \mathrm{~nm}$ were selected based on nighttime Raman measurements, and the lidar ratio at $1064 \mathrm{~nm}$ was obtained from AERONET measurements (Shin et al., 


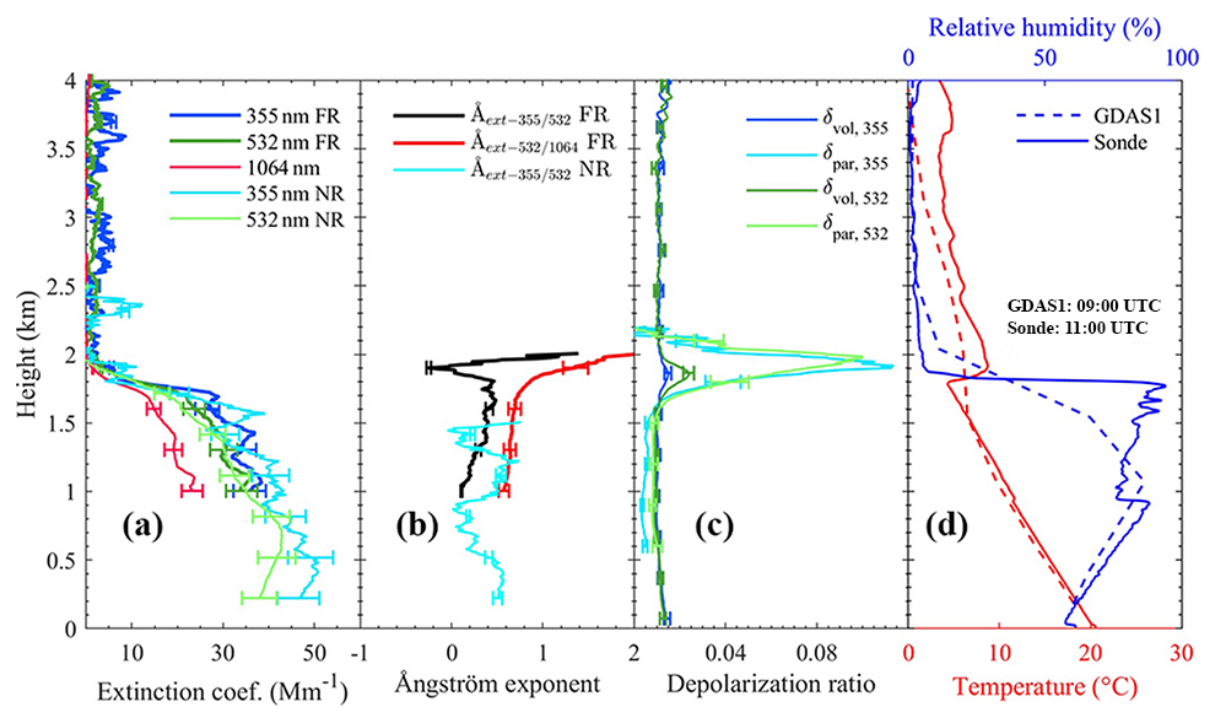

Figure 12. Height profiles of (a) particle extinction coefficients at $355 \mathrm{~nm}$ (blue, FR from far-range signal, NR from near-range signal), $532 \mathrm{~nm}$ (green) and $1064 \mathrm{~nm}$ (red), (b) Ångström exponents computed from different wavelength pairs in panel (a), (c) volume $\left(\delta_{\mathrm{vol}}\right)$ and particle $\left(\delta_{\text {par }}\right)$ depolarization ratios and (d) relative humidity (blue) and temperature (red). The lidar observations were taken on 23 November 2018 at 08:30-09:14 UTC. The radiosonde was launched at 11:00 UTC. GDAS1 data for 09:00 UTC are shown for comparison.

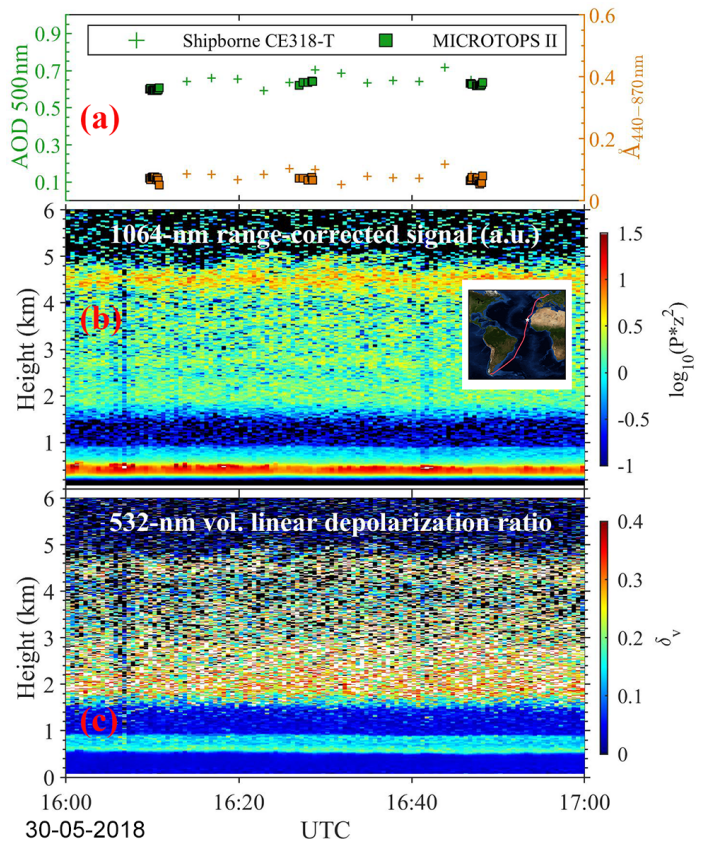

Figure 13. Aerosol observation with the shipborne CE318-T, MICROTOPS II and Polly XT lidar with strong dust loading on 30 May 2018. (a) Comparison of $500 \mathrm{~nm}$ AOD and Ångström exponent at 440-870 $\mathrm{nm}$ with shipborne CE318-T and MICROTOPS II, (b) the dust layer extending from 1.5 to $5 \mathrm{~km}$ and MBL reaching $0.6 \mathrm{~km}$, as indicated by the strong range-corrected signal at $1064 \mathrm{~nm}$ (red), and (c) volume depolarization ratios indicating the marine layer (low values, blue) and the Saharan dust layer (high values, green and yellow).
2018). Reference values of the backscatter coefficient were tuned to achieve the best agreement of AOD between lidar and shipborne CE318-T. Inside the MBL, mean extinction coefficients at 355 and $532 \mathrm{~nm}$ were found to be 245 and $241 \mathrm{Mm}^{-1}$ (Fig. 14a), respectively, which is very large compared to the values for pure marine conditions discussed in Sect. 3.2.1. This might be caused by the loading and hygroscopic growth of anthropogenic aerosols. This assumption is corroborated by the backward trajectories in Fig. 15a, because a branch of the backward trajectories arriving at $500 \mathrm{~m}$ can be traced back to the European continent. The lofted dust layer extended from 1.5 to $5 \mathrm{~km}$ with mean extinction coefficients of 166,161 and $159 \mathrm{Mm}^{-1}$ at 355,532 and $1064 \mathrm{~nm}$, and particle depolarization ratios of $0.21 \pm 0.05$ and $0.31 \pm 0.05$ at 355 and $532 \mathrm{~nm}$. These values are in good agreement with optical properties for pure Saharan dust reported earlier (Groß et al., 2011a, b; Tesche et al., 2009). The backward trajectories shown in Fig. 15b indicate that the air mass observed at $4 \mathrm{~km}$ height originated from Chad, Libya and Sudan, and traveled $6 \mathrm{~d}$ from these regions before reaching RV Polarstern. A relatively clean layer can be found between the lofted dust layer and MBL with extinction coefficients and particle depolarization ratios of below $25 \mathrm{Mm}^{-1}$ and 0.04 , respectively. Therefore, we are convinced that the sedimentation of dust particles was negligible in this case. Above the MBL, from 0.5 to $1 \mathrm{~km}$ height, an aerosol layer was presented that showed enhanced particle depolarization ratios at $355 \mathrm{~nm}(532 \mathrm{~nm})$ of $0.11(0.15)$. The backward trajectories for this layer were similar to the trajectories shown in Fig. 15a. Therefore, it probably consisted of relatively dry 


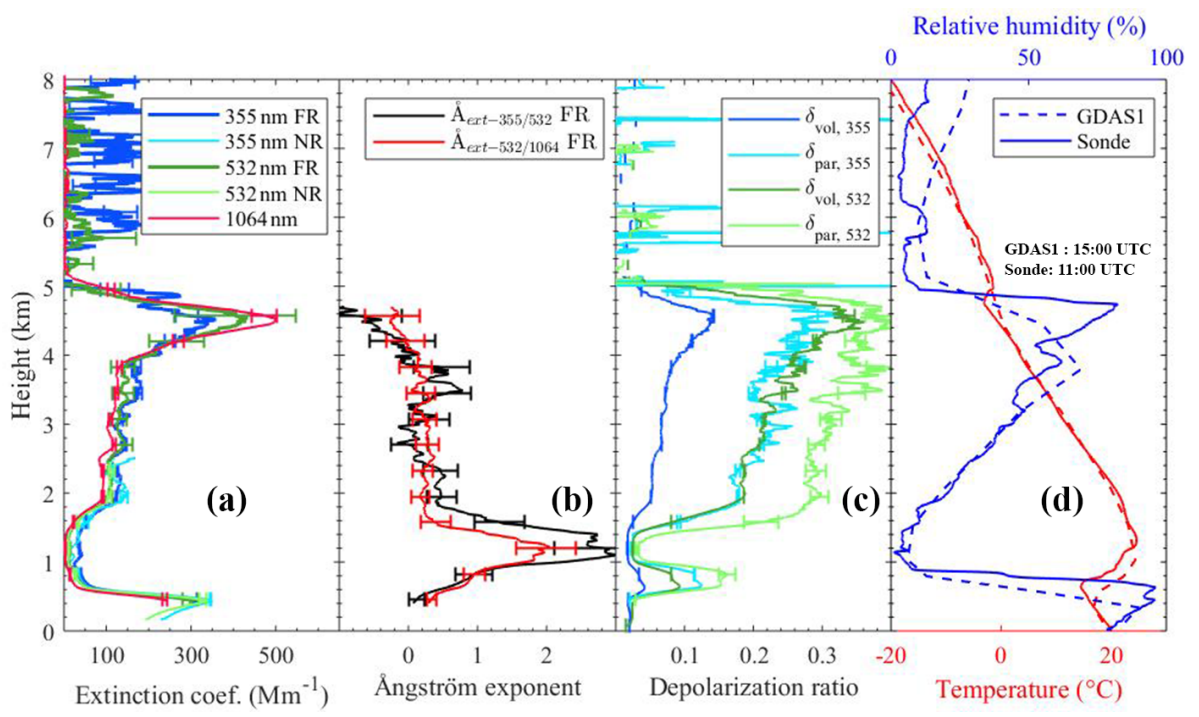

Figure 14. Height profiles of (a) particle extinction coefficients at $355 \mathrm{~nm}$ (blue, FR from far-range signal, NR from near-range signal), 532 (green) and $1064 \mathrm{~nm}$ (red), (b) Ångström exponents computed from different wavelength pairs in panel (a), (c) volume $\left(\delta_{\mathrm{vol}}\right)$ and particle $\left(\delta_{\text {par }}\right)$ depolarization ratios and (d) relative humidity (blue) and temperature (red). The lidar observations were taken on 30 May 2018 at 16:00-16:59 UTC. The radiosonde was launched at 11:00 UTC. GDAS1 data are for 15:00 UTC.

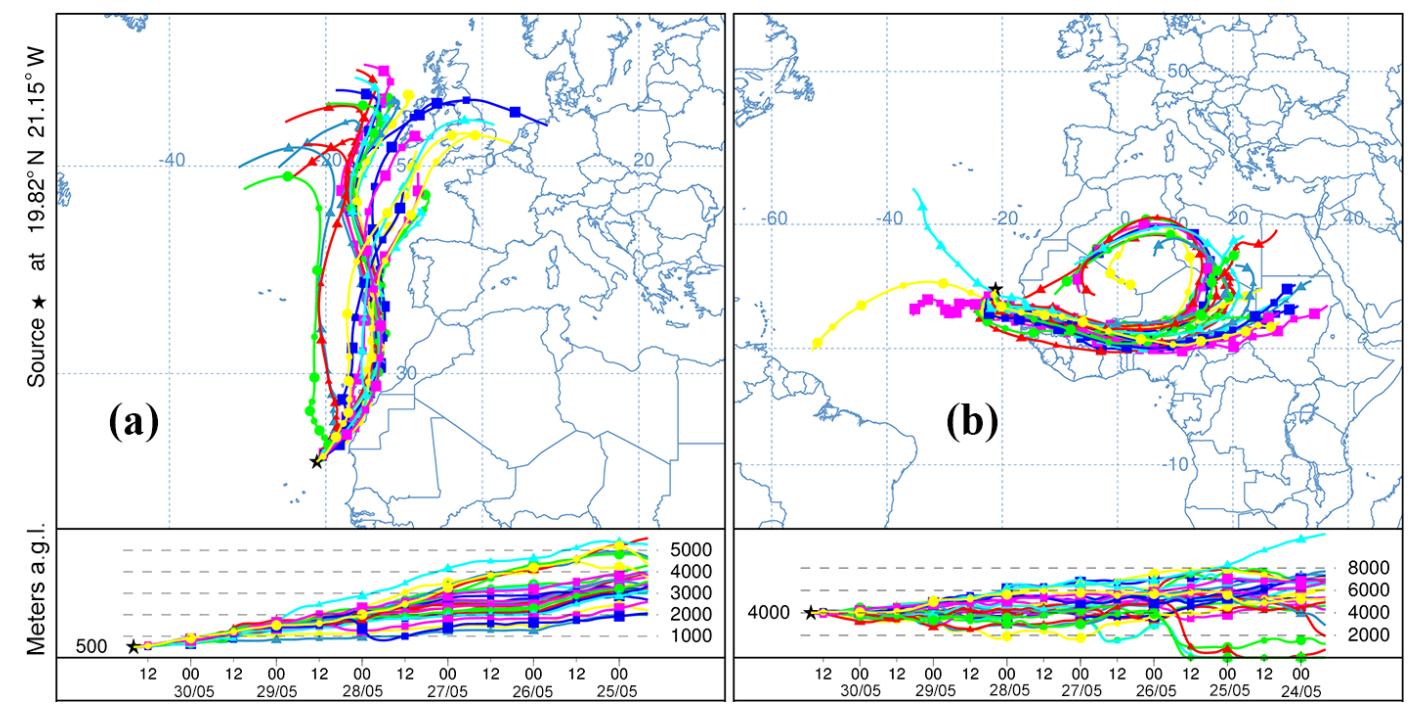

Figure 15. The $5 \mathrm{~d}$ HYSPLIT backward trajectory ensemble arriving at $500 \mathrm{~m}$ (a) and $6 \mathrm{~d}$ HYSPLIT backward trajectory ensemble arriving at $4000 \mathrm{~m}$ (b) height above RV Polarstern (black star) on 30 May 2018 at 16:00 UTC.

aged anthropogenic particles or a mixture of dry aged anthropogenic particles and dry sea salt particles.

\section{Conclusions}

Shipborne CE318-T measurements were conducted during two trans-Atlantic RV Polarstern cruises together with collocated observations from Polly ${ }^{\mathrm{XT}}$ lidar and an independent MICROTOPS II Sun photometer. The shipborne CE318-T has a special design to avoid contamination of sea spray and achieved the goal of automatic measurements over the ocean during the entire 4- to 5-week periods of the two cruises.

From linear regression and Bland-Altman plots, we found the capabilities of the shipborne CE318-T under the real oceanic conditions were as good as the manually operated MICROTOPS II to capture the daytime AOD variabilities. For nighttime measurements, deviations between the $532 \mathrm{~nm}$ AOD observed with Polly ${ }^{X T}$ and the shipborne CE318-T were found to be less than $10 \%$. 
The almucantar scanning option will also be implemented in the near future, which will enable the retrieval of aerosol microphysical properties over the ocean. All of these features will significantly increase our potential to characterize marine aerosol distribution over the remote ocean and the impact of continental dust, smoke and haze outbreaks on the aerosol conditions far away from the continents, as well as dust transport and dust sedimentation over the less exploited oceans.

Data availability. Radiosonde data have been archived in PANGAEA (https://doi.org/10.1594/PANGAEA.903864, https://doi.org/10.1594/PANGAEA.903888; Schmithüsen, 2019a, b). In addition, PollyXT data and quicklooks of the lidar measurements can be accessed on the PollyNET website (http://polly.rsd.tropos.de/, PollyNET, 2019). MICROTOPS II data can be downloaded from the AERONET MAN database (MAN). The shipborne CE318-T data can be accessed through contact with Philippe Goloub (philippe.goloub@univ-lille.fr).

Author contributions. ZP performed the lidar data analysis and prepared the manuscript together with AA. PS contributed greatly to the proofreading. MR, CJ and ZP set up the instruments for PS113 and were responsible for the lidar measurements. $\mathrm{AH}, \mathrm{KO}$ and $\mathrm{KH}$ set up the instruments during PS116 and were responsible for the lidar measurements during PS116. PG, LB, GD, SV and FM built up the shipborne CE318-T and were responsible for the corresponding data analysis. All authors contributed to scientific discussion and in this way to the manuscript preparation.

Competing interests. The authors declare that they have no conflict of interests.

Acknowledgements. The authors acknowledge funding from ACTRIS under grant agreement no. 262254, ACTRIS-2 under grant agreement no. 654109 from the European Union's Horizon 2020 research and innovation program, Labex CaPPA (the CaPPA project Chemical and Physical Properties of the Atmosphere) and the ESA/IDEAS program. We sincerely thank the Alfred Wegener Institute and the RV Polarstern crew members for their huge support and effort in PS113 and PS116 (acknowledgment nos. AWI_PS113_00, AWI_PS116_00). We also appreciate the effort of the AERONET MAN, HYSPLIT teams to provide the additional research data to solidify the analysis in the paper. Additionally, Zhenping Yin appreciates the support from the Chinese Scholarship Council (CSC) to conduct this research under CSC grant no. 201706270117.

Financial support. This research has been supported by the Horizon 2020 Research and Innovation program ACTRIS under grant agreement no. 262254, ACTRIS-2 under grant agreement no. 654109, Labex CaPPA and the ESA/IDEAS program.
The publication of this article was funded by the Open Access Fund of the Leibniz Association.

Review statement. This paper was edited by Andrew Sayer and reviewed by two anonymous referees.

\section{References}

Althausen, D., Engelmann, R., Baars, H., Heese, B., Ansmann, A., Müller, D., and Komppula, M.: Portable Raman lidar PollyXT for automated profiling of aerosol backscatter, extinction, and depolarization, J. Atmos. Ocean. Tech., 26, 2366-2378, https://doi.org/10.1175/2009jtecha1304.1, 2009.

Ångstrom, A.: The Parameters of Atmospheric Turbidity, Tellus, 16, 64-75, https://doi.org/10.1111/j.2153-3490.1964.tb00144.x, 1964.

Ansmann, A. and Müller, D.: Lidar and atmospheric aerosol particles, in: Lidar, Springer, 105-141, 2005.

Ansmann, A., Riebesell, M., Wandinger, U., Weitkamp, C., Voss, E., Lahmann, W., and Michaelis, W.: Combined Raman ElasticBackscatter Lidar for Vertical Profiling of Moisture, Aerosol Extinction, Backscatter, and Lidar Ratio, Appl. Phys. B-Photo., 55, 18-28, https://doi.org/10.1007/Bf00348608, 1992.

Ansmann, A., Wagner, F., Müller, D., Althausen, D., Herber, A., von Hoyningen-Huene, W., and Wandinger, U.: European pollution outbreaks during ACE 2: Optical particle properties inferred from multiwavelength lidar and star-Sun photometry, J. Geophys. Res.-Atmos., 107, AAC 8-1-AAC 8-14, https://doi.org/10.1029/2001jd001109, 2002.

Baars, H., Ansmann, A., Althausen, D., Engelmann, R., Heese, B., Muller, D., Artaxo, P., Paixao, M., Pauliquevis, T., and Souza, R.: Aerosol profiling with lidar in the Amazon Basin during the wet and dry season, J. Geophys. Res.-Atmos., 117, D21201, https://doi.org/10.1029/2012jd018338, 2012.

Baars, H., Kanitz, T., Engelmann, R., Althausen, D., Heese, B., Komppula, M., Preißler, J., Tesche, M., Ansmann, A., Wandinger, U., Lim, J.-H., Ahn, J. Y., Stachlewska, I. S., Amiridis, V., Marinou, E., Seifert, P., Hofer, J., Skupin, A., Schneider, F., Bohlmann, S., Foth, A., Bley, S., Pfüller, A., Giannakaki, E., Lihavainen, H., Viisanen, Y., Hooda, R. K., Pereira, S. N., Bortoli, D., Wagner, F., Mattis, I., Janicka, L., Markowicz, K. M., Achtert, P., Artaxo, P., Pauliquevis, T., Souza, R. A. F., Sharma, V. P., van Zyl, P. G., Beukes, J. P., Sun, J., Rohwer, E. G., Deng, R., Mamouri, R.-E., and Zamorano, F.: An overview of the first decade of Polly ${ }^{\text {NET }}$ : an emerging network of automated Raman-polarization lidars for continuous aerosol profiling, Atmos. Chem. Phys., 16, 5111-5137, https://doi.org/10.5194/acp16-5111-2016, 2016.

Barreto, Á., Cuevas, E., Granados-Muñoz, M.-J., AladosArboledas, L., Romero, P. M., Gröbner, J., Kouremeti, N., Almansa, A. F., Stone, T., Toledano, C., Román, R., Sorokin, M., Holben, B., Canini, M., and Yela, M.: The new sun-skylunar Cimel CE318-T multiband photometer - a comprehensive performance evaluation, Atmos. Meas. Tech., 9, 631-654, https://doi.org/10.5194/amt-9-631-2016, 2016.

Bland, J. M. and Altman, D.: Statistical methods for assessing agreement between two methods of clinical measure- 
ment, Lancet, 327, 307-310, https://doi.org/10.1016/s01406736(86)90837-8, 1986.

Bohlmann, S., Baars, H., Radenz, M., Engelmann, R., and Macke, A.: Ship-borne aerosol profiling with lidar over the Atlantic Ocean: from pure marine conditions to complex dust-smoke mixtures, Atmos. Chem. Phys., 18, 9661-9679, https://doi.org/10.5194/acp-18-9661-2018, 2018.

Draxler, R. R.: Hysplit (hybrid single-particle lagrangian integrated trajectory) model access via NOAA ARL ready website, available at: https://ready.arl.noaa.gov/HYSPLIT.php (last access: 28 February 2019), 2011.

Eck, T. F., Holben, B. N., Reid, J. S., Dubovik, O., Smirnov, A., O'Neill, N. T., Slutsker, I., and Kinne, S.: Wavelength dependence of the optical depth of biomass burning, urban, and desert dust aerosols, J. Geophys. Res.-Atmos., 104, 3133331349, https://doi.org/10.1029/1999jd900923, 1999.

Engelmann, R., Kanitz, T., Baars, H., Heese, B., Althausen, D., Skupin, A., Wandinger, U., Komppula, M., Stachlewska, I. S., Amiridis, V., Marinou, E., Mattis, I., Linné, H., and Ansmann, A.: The automated multiwavelength Raman polarization and water-vapor lidar Polly ${ }^{X T}$ : the neXT generation, Atmos. Meas. Tech., 9, 1767-1784, https://doi.org/10.5194/amt-9-1767-2016, 2016.

Fargion, G. S., McClain, C. R., Fukushima, H., Nicolas, J. M., and Barnes, R. A.: Ocean color instrument intercomparisons and cross-calibrations by the SIMBIOS Project, Sensors, Systems, and Next-Generation Satellites III, in: Sensors, Systems, and Next-Generation Satellites III, International Society for Optics and Photonics, https://doi.org/10.1117/12.494210, 397-403, 1999.

Fernald, F. G., Herman, B. M., and Reagan, J. A.: Determination of aerosol height distributions by lidar, J. Appl. Meteorol., 11, 482-489, 1972.

Freudenthaler, V., Esselborn, M., Wiegner, M., Heese, B., Tesche, M., Ansmann, A., Muller, D., Althausen, D., Wirth, M., Fix, A., Ehret, G., Knippertz, P., Toledano, C., Gasteiger, J., Garhammer, M., and Seefeldner, M.: Depolarization ratio profiling at several wavelengths in pure Saharan dust during SAMUM 2006, Tellus B, 61, 165-179, https://doi.org/10.1111/j.16000889.2008.00396.x, 2009.

Giavarina, D.: Understanding bland altman analysis, Biochem. Medica, 25, 141-151, https://doi.org/10.11613/bm.2015.015, 2015.

Goloub, P., Blarel, L., Dubios, G., Popovici, I., Podvin, T., Torres, B., Victori, S., Maupin, F., and Pikridas, M.: Current results on mobile system prototype development for Aerosol Cal/Val activities, ESA/IDEAS Project WP 3440-1/3/5, 12 December 2017.

Groß, S., Tesche, M., Freudenthaler, V., Toledano, C., Wiegner, M., Ansmann, A., Althausen, D., and Seefeldner, M.: Characterization of Saharan dust, marine aerosols and mixtures of biomassburning aerosols and dust by means of multi-wavelength depolarization and Raman lidar measurements during SAMUM 2, Tellus B, 63, 706-724, https://doi.org/10.3402/tellusb.v63i4.16369, $2011 \mathrm{a}$.

Groß, S., Wiegner, M., Freudenthaler, V., and Toledano, C.: Lidar ratio of Saharan dust over Cape Verde Islands: Assessment and error calculation, J. Geophys. Res.-Atmos., 116, D15203, https://doi.org/10.1029/2010JD015435, 2011b.
Haarig, M., Ansmann, A., Gasteiger, J., Kandler, K., Althausen, D., Baars, H., Radenz, M., and Farrell, D. A.: Dry versus wet marine particle optical properties: RH dependence of depolarization ratio, backscatter, and extinction from multiwavelength lidar measurements during SALTRACE, Atmos. Chem. Phys., 17, 1419914217, https://doi.org/10.5194/acp-17-14199-2017, 2017.

Holben, B. N., Tanre, D., Smirnov, A., Eck, T., Slutsker, I., Abuhassan, N., Newcomb, W., Schafer, J., Chatenet, B., and Lavenu, F.: An emerging ground-based aerosol climatology: Aerosol optical depth from AERONET, J. Geophys. Res.-Atmos., 106, 1206712097, https://doi.org/10.1029/2001jd900014, 2001.

Hsu, N., Jeong, M. J., Bettenhausen, C., Sayer, A., Hansell, R., Seftor, C., Huang, J., and Tsay, S. C.: Enhanced Deep Blue aerosol retrieval algorithm: The second generation, J. Geophys. Res.-Atmos., 118, 9296-9315, https://doi.org/10.1002/jgrd.50712, 2013.

Hughes, H. G., Ferguson, J. A., and Stephens, D. H.: Sensitivity of a lidar inversion algorithm to parameters relating atmospheric backscatter and extinction, Appl. Optics, 24, 1609-1613, https://doi.org/10.1364/ao.24.001609, 1985.

Ichoku, C., Levy, R., Kaufman, Y. J., Remer, L. A., Li, R. R., Martins, V. J., Holben, B. N., Abuhassan, N., Slutsker, I., and Eck, T. F.: Analysis of the performance characteristics of the five-channel Microtops II Sun photometer for measuring aerosol optical thickness and precipitable water vapor, J. Geophys. Res.-Atmos., 107, AAC 5-1-AAC 5-17, https://doi.org/10.1029/2001jd001302, 2002.

Kafle, D. and Coulter, R.: Micropulse lidar-derived aerosol optical depth climatology at ARM sites worldwide, J. Geophys. Res.Atmos., 118, 7293-7308, https://doi.org/10.1002/jgrd.50536, 2013.

Kanamitsu, M.: Description of the NMC global data assimilation and forecast system, Weather Forecast., 4, 335-342, 1989.

Kanitz, T.: Vertical distribution of aerosols above the Atlantic Ocean, Punta Arenas (Chile), and Stellenbosch (South Africa), Characterization, solar radiative effects and ice nucleating properties, https://doi.org/10.14279/depositonce-3386, 2012.

Kanitz, T., Ansmann, A., Engelmann, R., and Althausen, D.: Northsouth cross sections of the vertical aerosol distribution over the Atlantic Ocean from multiwavelength Raman/polarization lidar during Polarstern cruises, J. Geophys. Res.-Atmos., 118, 26432655, https://doi.org/10.1002/jgrd.50273, 2013.

Karol, Y., Tanré, D., Goloub, P., Vervaerde, C., Balois, J. Y., Blarel, L., Podvin, T., Mortier, A., and Chaikovsky, A.: Airborne sun photometer PLASMA: concept, measurements, comparison of aerosol extinction vertical profile with lidar, Atmos. Meas. Tech., 6, 2383-2389, https://doi.org/10.5194/amt-6-2383-2013, 2013.

Knobelspiesse, K., Tan, Q., Bruegge, C., Cairns, B., Chowdhary, J., van Diedenhoven, B., Diner, D., Ferrare, R., van Harten, G., and Jovanovic, V.: Intercomparison of airborne multi-angle polarimeter observations from the Polarimeter Definition Experiment, Appl. Optics, 58, 650-669, https://doi.org/10.1364/ao.58.000650, 2019.

Knobelspiesse, K. D., Pietras, C., Fargion, G. S., Wang, M., Frouin, R., Miller, M. A., Subramaniam, A., and Balch, W. M.: Maritime aerosol optical thickness measured by handheld sun photometers, Remote Sens. Environ., 93, 87-106, https://doi.org/10.1016/j.rse.2004.06.018, 2004. 
Livingston, J. M., Russell, P. B., Reid, J. S., Redemann, J., Schmid, B., Allen, D. A., Torres, O., Levy, R. C., Remer, L. A., and Holben, B. N.: Airborne Sun photometer measurements of aerosol optical depth and columnar water vapor during the Puerto Rico Dust Experiment and comparison with land, aircraft, and satellite measurements, J. Geophys. Res.-Atmos., 108, D19, https://doi.org/10.1029/2002jd002520, 2003.

Macke, A., Kalisch, J., Zoll, Y., and Bumke, K.: Radiative effects of the cloudy atmosphere from ground and satellite based observations, EPJ Web of Conferences, 83-94, 2010.

MAN: AERONET Maritime Aerosol Network database, available at: https://aeronet.gsfc.nasa.gov/new_web/maritime_aerosol_ network.html, last access: 4 February 2019.

Mattis, I., Ansmann, A., Müller, D., Wandinger, U., and Althausen, D.: Multiyear aerosol observations with dual-wavelength Raman lidar in the framework of EARLINET, J. Geophys. Res.-Atmos., 109, D13, https://doi.org/10.1029/2004jd004600, 2004.

Morys, M., Mims III, F. M., Hagerup, S., Anderson, S. E., Baker, A., Kia, J., and Walkup, T.: Design, calibration, and performance of MICROTOPS II handheld ozone monitor and Sun photometer, J. Geophys. Res.-Atmos., 106, 14573-14582, https://doi.org/10.1029/2001jd900103, 2001.

Müller, D., Ansmann, A., Mattis, I., Tesche, M., Wandinger, U., Althausen, D., and Pisani, G.: Aerosol-type-dependent lidar ratios observed with Raman lidar, J. Geophys. Res.-Atmos., 112, D16, https://doi.org/10.1029/2006jd008292, 2007.

PollyNET: PollyNET lidar database, available at: http://polly.rsd. tropos.de/, last access: 28 February 2019.

Rittmeister, F., Ansmann, A., Engelmann, R., Skupin, A., Baars, H., Kanitz, T., and Kinne, S.: Profiling of Saharan dust from the Caribbean to western Africa - Part 1: Layering structures and optical properties from shipborne polarization/Raman lidar observations, Atmos. Chem. Phys., 17, 12963-12983, https://doi.org/10.5194/acp-17-12963-2017, 2017.

Satheesh, S. and Moorthy, K. K.: Radiative effects of natural aerosols: A review, Atmos. Environ., 39, 2089-2110, 2005.

Sayer, A., Hsu, N., Lee, J., Bettenhausen, C., Kim, W., and Smirnov, A.: Satellite Ocean Aerosol Retrieval (SOAR) Algorithm Extension to S-NPP VIIRS as Part of the "Deep Blue" Aerosol Project, J. Geophys. Res.-Atmospheres, 123, 380-400, https://doi.org/10.1002/2017jd027412, 2018.

Schmithüsen, H.: Radiosonde measurements during POLARSTERN cruise PS113 (ANT-XXXIII/4), https://doi.org/10.1594/PANGAEA.903864, 2019a.

Schmithüsen, H.: Radiosonde measurements during POLARSTERN cruise PS116, https://doi.org/10.1594/PANGAEA.903888, 2019b.

Shin, S.-K., Tesche, M., Kim, K., Kezoudi, M., Tatarov, B., Müller, D., and Noh, Y.: On the spectral depolarisation and lidar ratio of mineral dust provided in the AERONET version 3 inversion product, Atmos. Chem. Phys., 18, 12735-12746, https://doi.org/10.5194/acp-18-12735-2018, 2018.
Smirnov, A., Holben, B. N., Kaufman, Y. J., Dubovik, O., Eck, T. F., Slutsker, I., Pietras, C., and Halthore, R. N.: Optical properties of atmospheric aerosol in maritime environments, J. Atmos. Sci., 59, 501-523, 2002.

Smirnov, A., Holben, B. N., Slutsker, I., Giles, D. M., McClain, C. R., Eck, T. F., Sakerin, S. M., Macke, A., Croot, P., Zibordi, G., Quinn, P. K., Sciare, J., Kinne, S., Harvey, M., Smyth, T. J., Piketh, S., Zielinski, T., Proshutinsky, A., Goes, J. I., Nelson, N. B., Larouche, P., Radionov, V. F., Goloub, P., Moorthy, K. K., Matarrese, R., Robertson, E. J., and Jourdin, F.: Maritime Aerosol Network as a component of Aerosol Robotic Network, J. Geophys. Res.-Atmos., 114, D6, https://doi.org/10.1029/2008jd011257, 2009.

Smirnov, A., Holben, B. N., Giles, D. M., Slutsker, I., O’Neill, N. T., Eck, T. F., Macke, A., Croot, P., Courcoux, Y., Sakerin, S. M., Smyth, T. J., Zielinski, T., Zibordi, G., Goes, J. I., Harvey, M. J., Quinn, P. K., Nelson, N. B., Radionov, V. F., Duarte, C. M., Losno, R., Sciare, J., Voss, K. J., Kinne, S., Nalli, N. R., Joseph, E., Krishna Moorthy, K., Covert, D. S., Gulev, S. K., Milinevsky, G., Larouche, P., Belanger, S., Horne, E., Chin, M., Remer, L. A., Kahn, R. A., Reid, J. S., Schulz, M., Heald, C. L., Zhang, J., Lapina, K., Kleidman, R. G., Griesfeller, J., Gaitley, B. J., Tan, Q., and Diehl, T. L.: Maritime aerosol network as a component of AERONET - first results and comparison with global aerosol models and satellite retrievals, Atmos. Meas. Tech., 4, 583-597, https://doi.org/10.5194/amt-4-583-2011, 2011.

Stocker, T.: Climate change 2013: the physical science basis: Working Group I contribution to the Fifth assessment report of the Intergovernmental Panel on Climate Change, Cambridge University Press, 2014.

Tesche, M., Ansmann, A., Muller, D., Althausen, D., Mattis, I., Heese, B., Freudenthaler, V., Wiegner, M., Esselborn, M., Pisani, G., and Knippertz, P.: Vertical profiling of Saharan dust with Raman lidars and airborne HSRL in southern Morocco during SAMUM, Tellus B, 61, 144-164, https://doi.org/10.1111/j.16000889.2008.00390.x, 2009.

Toledano, C., Cachorro, V., Berjon, A., De Frutos, A., Sorribas, M., De la Morena, B., and Goloub, P.: Aerosol optical depth and Ångström exponent climatology at El Arenosillo AERONET site (Huelva, Spain), Q. J. Roy. Meteor. Soc., 133, 795-807, https://doi.org/10.1002/qj.54, 2007.

Willmott, C. J.: Some comments on the evaluation of model performance, B. Am. Meteorol. Soc., 63, 1309-1313, 1982.

WMO: WMO/GAW Experts Workshop on a Global Surface-Based Network for Long Term Observations of Column Aerosol Optical Properties, edited by: Baltensperger, U., Barrie, L., and Wehrli, C., WMO/TD No. 1287, GAW Report No. 162, 2005. 